\title{
A Review Correlations between TPACK of Teacher towards Learning and Innovation Skills of Students
}

\author{
Oki Erfana Sulistyarini; Soetarno Joyoatmojo; Kristiani \\ Economic Education Department, Teacher Training and Education Faculty, Sebelas Maret University, Indonesia \\ http://dx.doi.org/10.18415/ijmmu.v9i2.3492
}

\begin{abstract}
The objectives of this research are to review the correlation of technological pedagogical and content knowledge (TPACK) which consisting of technology knowledge indicators, pedagogy knowledge, and content knowledge toward the learning and innovation skills of students which consisting of indicators of critical thinking, communication, collaboration and creativity. This research is a literature research by reviewing primary and secondary data sources. Data variable sources are 30 articles from the range of 2012 - 2021. The findings of the research showed that TPACK can affect the learning and innovation skills of students. The findings of this research can be used as a reference for future research.
\end{abstract}

Keywords: Learning and Innovation Skills; 4C; TPACK; The Competencies of Educators

\section{Introduction}

One of the objectives of the curriculum in Indonesia nowadays is to create graduates whose $21 \mathrm{st}$ century skills that have been integrated with $4 \mathrm{C}$ skills (critical thinking, communication, collaboration, creativity) which is called by learning and innovation kills (Ongardwanich, Kanjanawasee, \& Tuipae, 2015). It will strengthen that the competence of graduates is not only required to master hard skills but also soft skills needed in the world of industry (Musa, Mufti, Latiff, \& Amin, 2012).

One of the subjects which teach both of hard skills and soft skills; crafts and entrepreneurship are also one of the 21st century skills (Fong, Sidhu, \& Fook, 2014). However, the objectives of these subjects are to create the entrepreneurs in Indonesia that have not been effective. This is in line to the data on the number of Indonesian entrepreneurs which is increasing from $1.67 \%$ to $3.10 \%$ of the total population of Indonesian (225 million) in 2018. It is still far below of developed countries which average 12\%. (BPS, 2019). This shows the low level of learning and innovation 's kills students which can be caused by the lack of competence of educators in learning (Aznar-Díaz, Hinojo-Lucena, Cáceres-Reche, \& RomeroRodríguez, 2020). Therefore, it is needed to be a concern that educators always carry out competency tests and can fulfill the criteria needed to teach.

The competencies of educators based on Law number 14 year 2005 article 20 regarding to the educator's competencies, it states that they must have standard competencies that belongs within the 
TPACK framework, which covering pedagogy in the implementation of teaching and learning process, professionalism; the teacher's ability to master the subject content specifically and deeply, and is also obliged to improve and develop technological competence. This is in line to the core content of TPACK which is consisting of TK- technology knowledge, PK - pedagogy knowledge and CK- content knowledge (Henriksen, Mishra, \& Fisser, 2016). TPACK is a must-have for teachers, to help prepare students to think, learn, and master these 21st century skills (Cherner \& Smith, 2016). Indonesia applies the 2013 Curriculum (K13) which will be achieved if teachers combine TK, CK, and PK in the learning process in the classroom. The 2013 Curriculum suggests that teachers have the competence to deliver learning subjects (pedagogy knowledge), and the implementation of subject mastery (content knowledge) and mastery of technology (technology knowledge) called TPACK (Absari, Priyanto, \& Muslikhin, 2020). TPACK is essentials for teachers when implementing learning using technology in 21 st century education (Sahrir, Zaini, Hassan, Hamat, \& Ismail, 2021).

This finding is in line to the statement from Blömeke, Busse, Kaiser, König, \& Suhl (2016) which states that the integrated ability of educators starting from cognitive abilities and mastery of materials combined with pedagogical abilities is able to create effective learning in order to prepare good quality and competitive students. However, a different opinion was expressed by Jooste, Louw, Leipzig, Conradie, Asekun, Lucke, \& Hansen (2020) who stated that the success of educational programs is through material content and massive training that is adapted to the world of industry. In addition, the findings of research from Savage (2009) concludes that the use of technology does not have a substantive effect on student performance, which is means that the use of technology has not fully been able to improve learning and innovation skills of the students.

Based on these problems, it is important to research more about the correlation between the competences of educators, in this research is TPACK in creating learning and innovation skills. The importance of this research is to describe the factors that influence 21st century skills in the aspect of learning and innovation skills which are important skills to improve the quality of human resources. The novelty in this research is that there is no research or research that examines the correlation between the TPACK variable and the learning and innovation skills supported by Shafie, Majid, \& Ismail (2019) who research on the correlation between TPACK and 21 st century skills have not been widely and specifically discussed.

\section{Research Methodology}

This research is a literature research. The data research sources are various, consisting of primary, secondary and tertiary documents related to the research subject. Sources of literature in this research are 30 articles with the distribution of articles related to variables; 16 journals for the TPACK variable, 13 journals for the learning and innovation skills variable. (4C), and 12 journals for the TPACK variable on learning and innovation skills. The data taken in this research are in the form of researches and theories from journals and reference sources which discuss about learning and innovation skills students and the effects of TPACK. Data collection techniques used is collecting literature, classifying, quoting the necessary data, confirming data sources and grouping the data (Hamzah, 2020). Data analysis techniques used are data collection, data reduction, data display, and conclusion drawings (Bungin, 2010).

\section{Findings and Discussion}

According to table 1, the research data sources show the number and author of each TPACK variable, learning and innovation skills (4C), and the correlation between TPACK and learning innovation skills. 
Table 1. Source of Research Datas

\begin{tabular}{|c|c|c|}
\hline Variable & Amount & Author \\
\hline TPACK & 16 & $\begin{array}{l}\text { Brown, Neal, \& Fine (2012); Voogt et al. (2012); Cherner \& Smith } \\
\text { (2016); Henriksen, Mishra, \& Fisser (2016); Goradia (2018); Tseng } \\
\text { (2016); Harits, Sujadi, \& Slamet (2019); Khoza \& Biyela (2019); } \\
\text { Schilis \& Lyublinskaya (2019); Thinzarkyaw (2019); Absari, } \\
\text { Priyanto, \& Muslikhin (2020); Akbulut, Dindar, Küçük, \& Şeşen } \\
\text { (2020); Gan \& Zhang (2020); Hsu et al. (2020); Koh (2020); Sahrir et } \\
\text { al. (2021) }\end{array}$ \\
\hline $\begin{array}{l}\text { Learning and } \\
\text { Innovation } \\
\text { Skills (4C) }\end{array}$ & 13 & $\begin{array}{l}\text { Brown, Neal, \& Fine (2012); Greene, Yu, \& Copeland (2014); } \\
\text { Ongardwanich, Kanjanawasee, \& Tuipae (2015); Lee, Parsons, Kwon, } \\
\text { Kim, Petrova, Jeong, \& Ryu (2016); Van Laar, Van Deursen, Van } \\
\text { Dijk, \& De Haan (2017); Goradia (2018); Harits, Sujadi, \& Slamet } \\
\text { (2019); van Laar, van Deursen, van Dijk, \& de Haan (2018); Absari, } \\
\text { Priyanto, \& Muslikhin (2020); Aznar-Díaz, Hinojo-Lucena, Cáceres- } \\
\text { Reche, \& Romero-Rodríguez (2020); van Laar, van Deursen, van } \\
\text { Dijk, \& de Haan (2020) }\end{array}$ \\
\hline $\begin{array}{l}\text { Relationship } \\
\text { TPACK } \\
\text { towards } \\
\text { Learning and } \\
\text { Innovation } \\
\text { Skills (4C) }\end{array}$ & 12 & $\begin{array}{l}\text { Brown, Neal, \& Fine (2012); Pheeraphan (2013); Thang et al. (2014); } \\
\text { Siddiq, Scherer, \& Tondeur (2016); Chang et al. (2017); } \\
\text { Dukuzumuremyi \& Siklander (2018); Goradia (2018); Harits, Sujadi, } \\
\text { \& Slamet (2019); Hong, Lin, \& Lee (2019); Shafie, Majid, \& Ismail } \\
\text { (2019); Absari, Priyanto, \& Muslikhin (2020); van Laar, van Deursen, } \\
\text { van Dijk, \& de Haan (2020) }\end{array}$ \\
\hline
\end{tabular}

Meanwhile, the distribution of articles based on the year of publication can be seen in Figure 1, which is the most widely used and reviewed articles in this research were taken from 2020 and 2016 which indicates both of those years were many research with the topic of learning and innovation skills and/or TPACK.

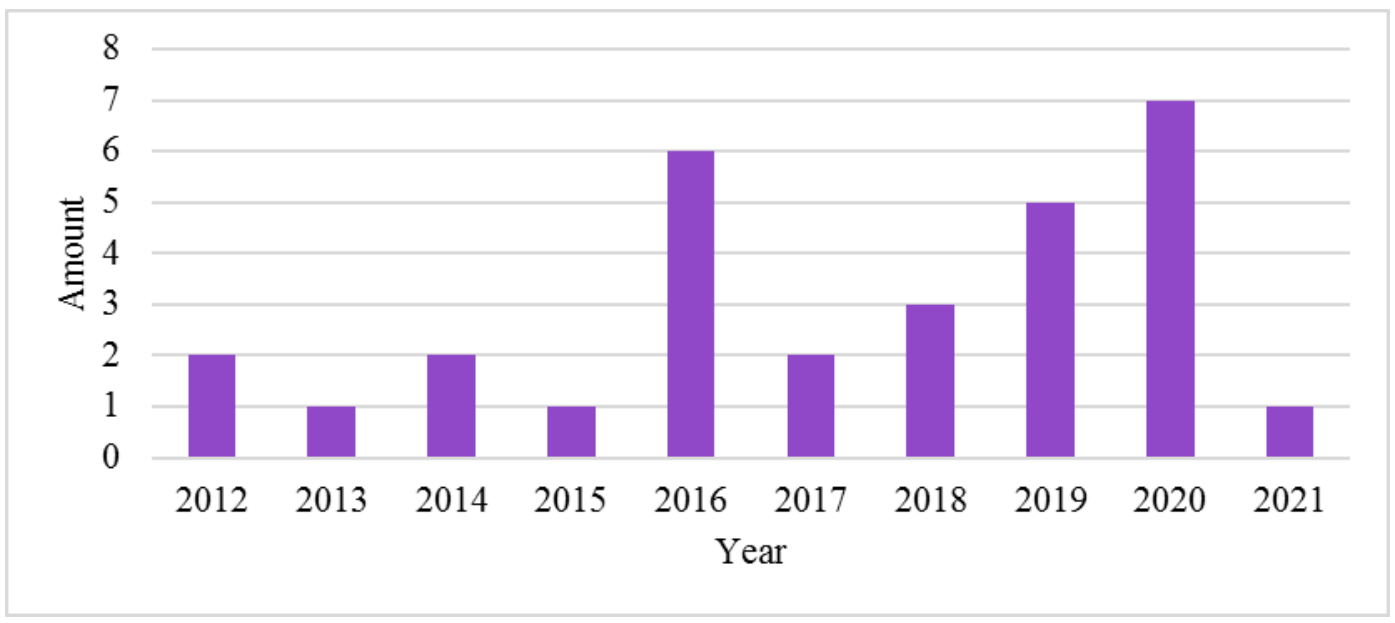

Figure 1. Distribution of Articles by Year

Based on the objectives of this research that can be seen in figure 1, the conceptual framework, TPACK consistsing of technology knowledge, pedagogy knowledge, and content knowledge that can affect the learning and innovation skills of students which consist of critical thinking, communication, collaboration, and creativity. 


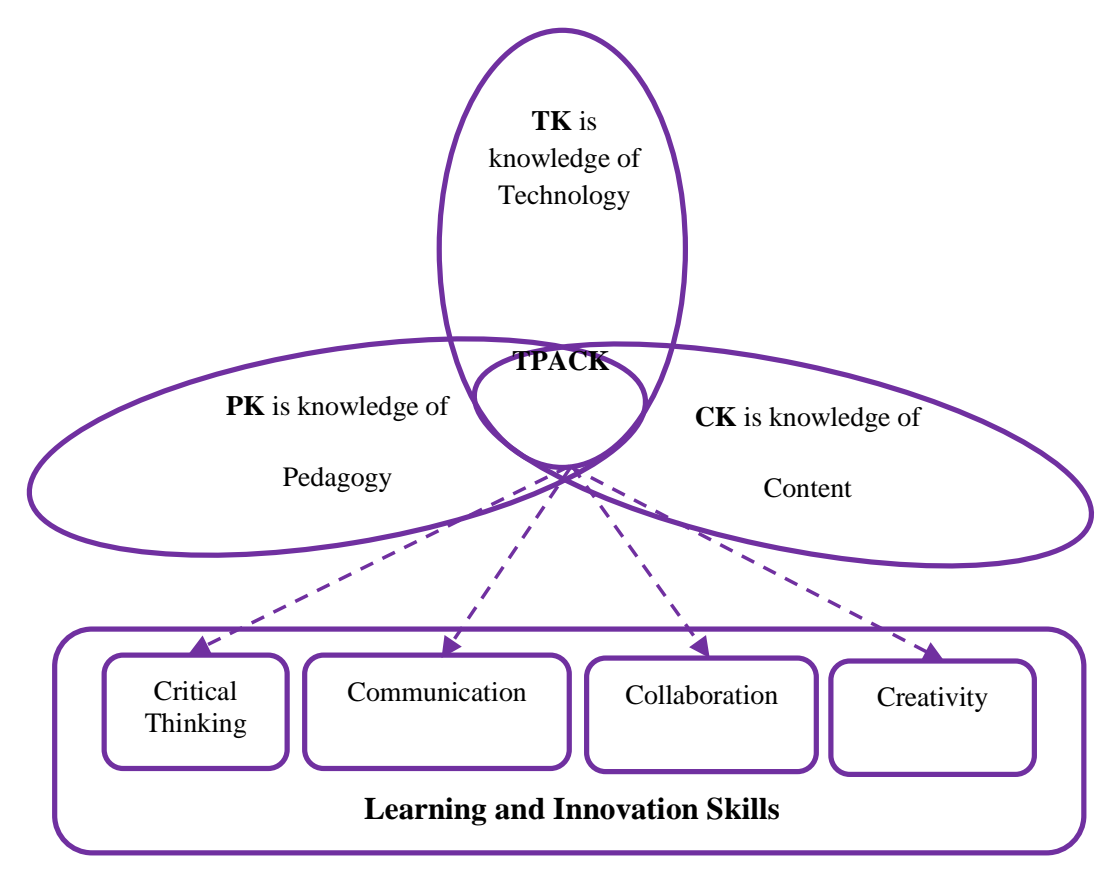

Figure 2. Conceptual Framework

\section{Learning and Innovation Skills (4C)}

According to Ongardwanich, Kanjanawasee, \& Tuipae (2015)one of the $21^{\text {st }}$ century digital skills are learning and innovation skills which is also called by $4 \mathrm{C}$ that consisting of critical thinking, communication, collaboration and creativity.

Critical thinking is a skill that enables students to analyze evidence, clarify, justify, relate the ideas, novelty and form the judgments to solve problems (Goradia, 2018; Greene, Yu, \& Copeland, 2014; Lee, Parsons, Kwon, Kim, Petrova, Jeong, \& Ryu, 2016; Van Laar, Van Deursen, Van Dijk, \& De Haan, 2017)

Communication is a skill that allows students to effectively convey ideas and transmit information among other students through certain media (Goradia, 2018; van Laar, van Deursen, van Dijk, \& de Haan, 2020).

Collaboration is a process of making students work together to find solutions to a certain problem as well as skills to develop social networks and work in groups to exchange information, and make decisions with mutual appreciation and respect for each other to achieve common goals. (Goradia, 2018; van Laar, van Deursen, van Dijk, \& de Haan, 2018).

Creativity is enabling students to review concepts from different perspectives which ultimately leads to innovation or generating new or previously unknown ideas into a product, service, or process that is recognized as something new. (Goradia, 2018; Van Laar, Van Deursen, Van Dijk, \& De Haan, 2017).

\section{Technological Pedagogical and Content Knowledge (TPACK)}

TPACK is a new knowledge system formed by the integration and reconstruction of technological knowledge, pedagogic knowledge and content knowledge as a basis for teachers to use technology in order to create effective learning (Cherner \& Smith, 2016; Gan \& Zhang, 2020). A high 
qualified teacher must able to design and implement a teaching program based on his own TPACK (Akbulut, Dindar, Küçük, \& Şeşen, 2020). Knowledge of technology, pedagogy, and content as a taxonomy of learning can address needs related to subjects, individuals and community needs through the integration of technology (Khoza \& Biyela, 2019). Definition of TPACK separately as mentioned by Akbulut, Dindar, Küçük, \& Şeşen (2020), Schilis \& Lyublinskaya (2019), Koh (2020), Thinzarkyaw (2019), and Tseng (2016); TK-technology knowledge, PK-pedagogy knowledge, and TK-technology knowledge.

TK (Technology Knowledge) is a knowledge of using technological tools from the advanced technology including the internet, operating systems, computer equipment, as well as simple traditional tools such as chalk, books, and blackboards.

PK (Pedagogy Knowledge) is a knowledge of learning theories and methodologies needed to develop appropriate instruction related to practice during the learning process, including knowledge of learning methods, learning approaches, learning models, class management, lesson planning, and student evaluation methods at school.

CK (Content Knowledge) is an insight or knowledge about content or subject matter; economic material concerning the subject matter being studied or taught, such as knowledge of concepts, theories, and ideas.

\section{The Effect of TPACK Toward the Learning and Innovation Skill Using Integration Technology}

The importance of mastering learning and innovation skills is needed because the students have to keep up-date with technological developments (Absari, Priyanto, \& Muslikhin, 2020). TPACK of teachers as the basic framework for learning and innovation skills or 4C (Brown, Neal, \& Fine, 2012). In line from Goradia (2018) that teachers play an important role in supporting students' creativity, critical thinking, collaboration and lifelong learning skills, including communication in it.

Content knowledge refers to the lessons taught by the teacher, pedagogical knowledge refers to how the teacher delivers the material, and technological knowledge refers to the teacher's knowledge of integrating technology in teaching, especially in 21st century education (Sahrir et al., 2021; Voogt, Fisser, Pareja Roblin, Tondeur, \& van Braak, 2012). TPACK teachers help and provide teachers' abilities and skills to apply technology in learning process (Absari, Priyanto, \& Muslikhin, 2020; Goradia, 2018; Hsu, Liang, Chuang, Chai, \& Tsai, 2020). According to Hong, Lin, \& Lee (2019), the use of technology, especially information and communication technology (ICT) in education has increased access to education and learning with the assist of technology.

Moreover, technology, especially digital assessment, plays an important role in creating high quality graduates, especially in digital information technology that improves 21st century skills, especially critical thinking skills (van Laar, van Deursen, van Dijk, \& de Haan, 2020). The existence of technology can help collaboration between students to think critically to solve problems given by the teacher (Chang et al., 2017). K13 with technology integration, the advantage for the students to make them more creative and innovative in utilizing the technology provided (Absari, Priyanto, \& Muslikhin, 2020). One of the example that can be taken in correlation to these two variables is the research from Thang, Sim, Mahmud, Lin, Zabidi, \& Ismail (2014) which uses instruments in the form of digital equipment in learning to obtain and process digital information can improve creativity and collaboration skills with one another. The use of technology can have a positive and significant effect on the effectiveness of collaboration between teachers and students in one classroom (Dukuzumuremyi \& Siklander, 2018). One of the efforts to develop 21st century skills with the integration of ICT in classroom learning can improve communication skills (Pheeraphan, 2013; Siddiq, Scherer, \& Tondeur, 2016). 
TPACK to integrating technology

- Voogt, Fisser, Pareja Roblin, Tondeur, \& van Braak (2012)

- Goradia (2018)

- Absari, Priyanto, \& Muslikhin (2020)

- Hsu, Liang, Chuang, Chai, \& Tsai (2020)

\section{Integrating technology to} communication

- Pheeraphan (2013)

- Siddiq, Scherer, \& Tondeur (2016)
Integrating technology to creativity

- Absari, Priyanto, \& Muslikhin (2020)

- Thang et al. (2014)

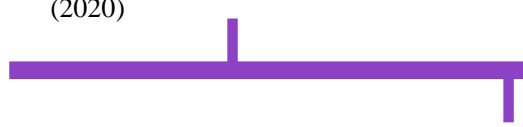

Integrating technology to critical thinking

- Chang et al. (2017)

- van Laar, van Deursen, van Dijk, \& de Haan (2020)
Integrating technology to collaboration

- Thang, Sim, Mahmud, Lin, Zabidi, \& Ismail (2014)

- Dukuzumuremyi \& Siklander (2018)

Figure 3. Meta Analysis TPACK to 4C with Technology

\section{The Effect of TPACK Toward Learning and Innovation Skills}

TPACK of the teacher's ability to build students' creativity, innovative and able to compete with other countries in the information era (Absari, Priyanto, \& Muslikhin, 2020). TPACK supports critical thinking, creative, collaborative, communication in groups (Brown, Neal, \& Fine, 2012). In Goradia (2018) TPACK with components technology use can form discussion forums as a forum for communication between teachers and students and students with other students and provide opportunities for collaborative learning. In addition, it encourages students to re-think innovative ways to utilize technology to make students' creativity get improved. The pedagogy encourages the content delivered by the teacher to be more in-depth so as to encourage students to think critically. Better content knowledge by utilizing technology can be used creatively and innovatively.

According to Harits, Sujadi, \& Slamet (2019) the application of TPACK with learning approaches such as scaffolding and questions based on Higher Order Thinking (HOT) in the classroom can help students to think critically. TPACK has a significant effect on the development of students' communication skills. Giving freedom students to ask questions and express opinions in the learning process, it will keep them to develop students' communication skills. Discussion with the teacher is also a factor that can develop students' communication skills. The application of TPACK with the cooperative learning model in applying TPACK can help students to collaborate with their peers and communicate skills during presentations. Finally, TPACK is presented with a variety of creative interactive media that will be more interactive and can develop students' creativity and innovation in learning.

TPACK to critical thinking

- Brown, Neal, \& Fine (2012).

- Goradia (2018)

- Harits, Sujadi, \& Slamet (2019)
TPACK to colaborative

- Brown, Neal, \& Fine (2012).

- Goradia (2018)

- Harits, Sujadi, \& Slamet (2019)

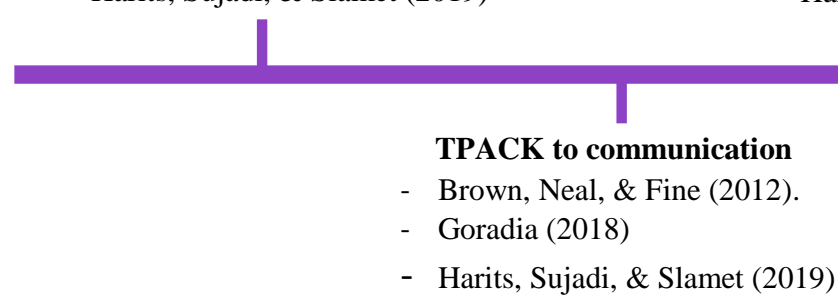

TPACK to creativity

- Brown, Neal, \& Fine (2012).

- Goradia (2018)

- Absari, Priyanto, \& Muslikhin (2020)

- Harits, Sujadi, \& Slamet (2019)

Figure 4. Meta Analysis TPACK to 4C 
TPACK has an effect on the learning and innovation skills of students, this is in line to Goradia (2018)stated that TPACK can improve $21^{\text {st }}$ century learning and innovation skills. Also in Harits, Sujadi, \& Slamet (2019)using TPACK develops $21^{\text {st }}$ century students' skills (4C). Also Shafie, Majid, \& Ismail (2019)mentioned that TPACK has an effect on $21^{\text {st }}$ century skills in classroom, covering communication, collaboration, critical thinking and creative thinking. TPACK teachers as the basic framework for 4C skills including critical and creative thinking; collaborative processes and problem solving (Brown, Neal, \& Fine, 2012). Supported by Goradia (2018)that teachers play an important role in supporting students' creativity, critical thinking, collaboration and life-long learning skills.

\section{Conclusion}

Learning and innovation skills as the $21^{\text {st }}$ elements century skills that can be used to develop the quality of human resources have four main indicators; consisting of critical thinking skills, communication, collaboration, and creativity. This ability can be formed in various ways. One of them is through the process of education or training. This education is strongly influenced by the transfer of knowledge and skills carried out by teachers. Teachers must have TPACK in order to do learning process well. Through TPACK by a high quality teacher, students' learning and innovation skills can be improved effectively.

In addition, in the application of TPACK cannot be separated from the use of technology that can encourage the emergence of collaboration and communication between students to solve problems given by the teacher. Specifically, the correlation between the TPACK variable and learning and innovation skills is deep and broad content, one of way is High Order Thinking that can improve students' critical thinking, the use of technology or media encourages students to obtain and process information, it also will encourage creativity to process and produce information. Moreover, it relates to collaboration and communication skills based on the learning process that requires students to communicate well with the teacher when the question-answer method or peer's discussion methods that also encourage the collaboration. In short, the conclusion of TPACK is able to improve students' learning and innovation skills.

\section{References}

Absari, N., Priyanto, P., \& Muslikhin, M. (2020). The Effectiveness of Technology, Pedagogy and Content Knowledge (TPACK) in Learning. Jurnal Pendidikan Teknologi dan Kejuruan, 26(1), 43-51. doi:10.21831/jptk.v26i1.24012

Akbulut, C. K., Dindar, A. Ç., Küçük, S., \& Şeşen, B. A. (2020). Development and Validation of the ICTTPACK-Science Scale. Journal of Science Education and Technology, 29(3), 355-368. doi:10.1007/s10956-020-09821-z

Aznar-Díaz, I., Hinojo-Lucena, F.-J., Cáceres-Reche, M.-P., \& Romero-Rodríguez, J.-M. (2020). Pedagogical Approaches in the Knowledge Society: The Flipped Classroom Method for the Development of Creativity and Dialogical Learning. International Journal of Emerging Technologies in Learning (iJET), 15(03), 4. doi:10.3991/ijet.v15i03.11664

Blömeke, S., Busse, A., Kaiser, G., König, J., \& Suhl, U. (2016). The Relation Between Content-Specific and General Teacher Knowledge and Skills. Teaching and Teacher Education, 56, 35-46. doi:10.1016/j.tate.2016.02.003 
BPS, S. I. (2019). Statistik Indonesia 2019 Statistical Yearbook of Indonesia. In S.-d. o. S. C. a. Publication (Ed.). Jakarta: Central Bureau of Statistics, Indonesia.

Brown, C. A., Neal, R. E., \& Fine, B. (2012). Using 21st Century Thinking Skills Applied to the TPACK Instructional Model. 21 - 28.

Bungin, B. (2010). Metodologi Penelitian Kualitatif. Jakarta: PT Raja Grafindo Persada.

Chang, C.-J., Chang, M.-H., Chiu, B.-C., Liu, C.-C., Fan Chiang, S.-H., Wen, C.-T., . . Chen, W. (2017). An Analysis of Student Collaborative Problem Solving Activities Mediated by Collaborative Simulations. Computers \& Education, 114, 222-235. doi:10.1016/j.compedu.2017.07.008

Cherner, T., \& Smith, D. (2016). Reconceptualizing TPACK to Meet the Needs of Twenty-First-Century Education. The New Educator, 13(4), 329-349. doi:10.1080/1547688x.2015.1063744

Dukuzumuremyi, S., \& Siklander, P. (2018). Interactions Between Pupils and Their Teacher in Collaborative and Technology-Enhanced Learning Settings in The Inclusive Classroom. Teaching and Teacher Education, 76, 165-174. doi:10.1016/j.tate.2018.08.010

Fong, L. L., Sidhu, G. K., \& Fook, C. Y. (2014). Exploring 21st Century Skills among Postgraduates in Malaysia. Procedia - Social and Behavioral Sciences, 123, 130-138. doi:10.1016/j.sbspro.2014.01.1406

Gan, B., \& Zhang, C. (2020). Research on the Design and Construction of University Informationized Learning Environment under the TPACK Framework. Journal of Physics: Conference Series, 1550, 032064. doi:10.1088/1742-6596/1550/3/032064

Goradia, T. (2018). Role of Educational Technologies Utilizing the TPACK Framework and 21st Century Pedagogies: Academics' Perspectives. IAFOR Journal of Education, 6(3), 43 - 61.

Greene, J. A., Yu, S. B., \& Copeland, D. Z. (2014). Measuring Critical Components of Digital Literacy and Their Relationships with Learning. Computers \& Education, 76, 55-69. doi:10.1016/j.compedu.2014.03.008

Hamzah, A. (2020). Metode Penelitian Kepustakaan (Library Research). Malang: Literasi Nusantara.

Harits, M., Sujadi, I., \& Slamet, I. (2019). Technological, Pedagogical, and Content Knowledge Math Teachers: To Develop 21st Century Skills Students. Journal of Physics: Conference Series, 1321(3), 032011. doi:10.1088/1742-6596/1321/3/032011

Henriksen, D., Mishra, P., \& Fisser, P. (2016). Infusing Creativity and Technology in 21st Century Education: A Systemic View for Change. Educational Technology \& Society, 19(3), 27-37.

Hong, H.-Y., Lin, P.-Y., \& Lee, Y.-H. (2019). Developing Effective Knowledge-Building Environments through Constructivist Teaching Beliefs and Technology-Integration Knowledge: A Survey of Middle-School Teachers in Northern Taiwan. Learning and Individual Differences, 76, 101787. doi:10.1016/j.lindif.2019.101787

Hsu, C. Y., Liang, J. C., Chuang, T. Y., Chai, C. S., \& Tsai, C. C. (2020). Probing in-service elementary school teachers' perceptions of TPACK for games, attitudes towards games, and actual teaching usage: a study of their structural models and teaching experiences. Educational Studies, 1-17. doi:10.1080/03055698.2020.1729099 
Jooste, J. L., Louw, L., Leipzig, K. V., Conradie, P. D. F., Asekun, O. O., Lucke, D., \& Hansen, D. H. (2020). Teaching Maintenance Plan Development in A Learning Factory Environment. 10th Conference on Learning Factories, CLF2020, 45, 379 - 385.

Khoza, S. B., \& Biyela, A. T. (2019). Decolonising technological pedagogical content knowledge of first year mathematics students. Education and Information Technologies, 25(4), 2665-2679. doi:10.1007/s10639-019-10084-4

Koh, J. H. L. (2020). Three approaches for supporting faculty technological pedagogical content knowledge (TPACK) creation through instructional consultation. British Journal of Educational Technology. doi:10.1111/bjet.12930

Lee, H., Parsons, D., Kwon, G., Kim, J., Petrova, K., Jeong, E., \& Ryu, H. (2016). Cooperation Begins: Encouraging Critical Thinking Skills through Cooperative Reciprocity Using a Mobile Learning Game. Computers \& Education, 97, 97-115. doi:10.1016/j.compedu.2016.03.006

Musa, F., Mufti, N., Latiff, R. A., \& Amin, M. M. (2012). Project-based Learning (PjBL): Inculcating Soft Skills in 21st Century Workplace. Procedia - Social and Behavioral Sciences, 59, 565-573. doi:10.1016/j.sbspro.2012.09.315

Ongardwanich, N., Kanjanawasee, S., \& Tuipae, C. (2015). Development of 21st Century Skill Scales as Perceived by Students. Procedia - Social and Behavioral Sciences, 191, 737-741. doi:10.1016/j.sbspro.2015.04.716

Pheeraphan, N. (2013). Enhancement of the 21st Century Skills for Thai Higher Education by Integration of ICT in Classroom. Procedia - Social and Behavioral Sciences, 103, 365-373. doi:10.1016/j.sbspro.2013.10.346

Sahrir, M. S., Zaini, A. R., Hassan, Y., Hamat, Z., \& Ismail, T. (2021). Employing Technological Pedagogical Content Knowledge (TPACK) Skill Among Teachers in Preparing Online School Assessment for Home-Based Learning. IJAZ ARABI Journal of Arabic Learning, 4(2), 285 - 297. doi:10.18860/ijazarabi.v4i2.11493

Savage, S. J. (2009). The Effect of Information Technology on Economic Education. The Journal of Economic Education, 40(4), 337-353. doi:10.1080/00220480903237901

Schilis, A. K., \& Lyublinskaya, I. (2019). Analysis of Relationship Between Five Domains of TPACK Framework: TK, PK, CK Math, CK Science, and TPACK of Pre-service Special Education Teachers. Technology, Knowledge and Learning, 25(1), 25-43. doi:10.1007/s10758-019-09404-x

Shafie, H., Majid, F. A., \& Ismail, I. S. (2019). Technological Pedagogical Content Knowledge (TPACK) in Teaching 21st Century Skills in the 21st Century Classroom. Asian Journal of University Education, 24 - 33. doi:10.24191/ajue.v15i3.7818

Siddiq, F., Scherer, R., \& Tondeur, J. (2016). Teachers' Emphasis on Developing Students' Digital Information and Communication Skills (TEDDICS): A New Construct in 21st Century Education. Computers \& Education, 92-93, 1-14. doi:10.1016/j.compedu.2015.10.006

Thang, S. M., Sim, L. Y., Mahmud, N., Lin, L. K., Zabidi, N. A., \& Ismail, K. (2014). Enhancing 21st Century Learning Skills Via Digital Storytelling: Voices of Malaysian Teachers and Undergraduates. Procedia - Social and Behavioral Sciences, 118, 489-494. doi:10.1016/j.sbspro.2014.02.067 
Thinzarkyaw, W. (2019). The Practice of Technological Pedagogical Content Knowledge of Teacher Educators in Education Colleges in Myanmar. Contemporary Educational Technology, 11(2). doi:10.30935/cet.660829

Tseng, J.-J. (2016). Developing an instrument for assessing technological pedagogical content knowledge as perceived by EFL students. Computer Assisted Language Learning, 29(2), 302-315. doi:10.1080/09588221.2014.941369

Undang-Undang Nomor 14 Tahun 2005 Retrieved from luk.staff.ugm.ac.id/atur/UU142005GuruDosen.pdf

Van Laar, E., Van Deursen, A. J. A. M., Van Dijk, J. A. G. M., \& De Haan, J. (2017). The relation between 21st-century skills and digital skills: A systematic literature review. Computers in Human Behavior, 72, 577-588. doi:10.1016/j.chb.2017.03.010

van Laar, E., van Deursen, A. J. A. M., van Dijk, J. A. G. M., \& de Haan, J. (2018). 21st-Century Digital Skills Instrument Aimed at Working Professionals: Conceptual Development and Empirical Validation. Telematics and Informatics, 35(8), 2184-2200. doi:10.1016/j.tele.2018.08.006

van Laar, E., van Deursen, A. J. A. M., van Dijk, J. A. G. M., \& de Haan, J. (2020). Determinants of 21stCentury Skills and 21st-Century Digital Skills for Workers: A Systematic Literature Review. SAGE Open, 10(1), 215824401990017. doi:10.1177/2158244019900176

Voogt, J., Fisser, P., Pareja Roblin, N., Tondeur, J., \& van Braak, J. (2012). Technological Pedagogical Content Knowledge - A Review of The Literature. Journal of Computer Assisted Learning, 29(2), 109-121. doi:10.1111/j.1365-2729.2012.00487.x

\section{Copyrights}

Copyright for this article is retained by the author(s), with first publication rights granted to the journal.

This is an open-access article distributed under the terms and conditions of the Creative Commons Attribution license (http://creativecommons.org/licenses/by/4.0/). 